\title{
Subjektivní teorie učitelů o výukové komunikaci
}

\author{
Teacher's belief on educational communication \\ Zuzana Šalamounová, Roman Švaříček
}

\begin{abstract}
Anotace: Předložený příspěvek se zabývá výukovou komunikací a jejím pojetím ze strany učitelů. Na základě analýzy opakovaných rozhovorů s šestnácti učiteli humanitních předmětů na druhém stupni základní školy se věnujeme tomu, jak sami učitelé vnímají komunikaci, která ve školní třídě nastává mezi nimi a jejich žáky. Z výsledků analýzy pak vyplývá snaha učitelů o směřování ke konstruktivistickému nastavení výukové komunikace, identifikovány jsou však také důvody, vzhledem ke kterým je implementace těchto snah do každodenní školní reality prozatím v půli cesty mezi IRF strukturou a dialogickou výukou.
\end{abstract}

Klíčová slova: výuková komunikace, subjektivní teorie učitelů, IRF struktura, diskuse

\begin{abstract}
It is apparent that the result of educational communication is mostly dependant on teachers: for it is them who organize utterances according to their judgment, they choose who is about to speak, they stop utterances. The goal of this paper is therefore to answer the following research question: how do teachers at secondary Czech schools (ISCED 2A) perceive educational communication? Answering this question allows us to identify the ideal types of educational communication which determine the real results of this communication and which thus help to define the overall character of the educational process.
\end{abstract}

Keywords: educational communication, subjective theories of teachers, IRF structure, discussion

\section{1 Úvodem}

Komunikace má v procesu vzdělávání a učení nezpochybnitelnou roli. Jak poznamenávají např. Hurt et al. (1978 in Mottet, Beebe, 2006; dále např. McCroskey, 1983, 2005), vědomosti jsou samy o sobě hodnotné, nicméně bez ohledu na to, kolik toho učitel ví, negarantuje šíre jeho vědomostí, že je bude umět předat. Právě komunikace je tak klíčovou spojnicí mezi učitelem, který disponuje vědomostmi, a učícím se žákem. V tomto příspěvku se orientujeme prímo na výukovou komunikaci, jíž označujeme ty komunikační sekvence, které jsou orientovány pouze na učební obsahy. Nejedná se tedy o komunikaci, která taktéž nastává v průběhu vyučování, ale jejímž obsahem jsou mimovýukové či organizační záležitosti (srov. Šed’ová et al., 2011).

Ke zkoumání výukové komunikace přitom přistupujeme méně obvyklou cestou, nebot' vycházíme z rozhovorů s učiteli (srov. Mercer, 2010). Toto rozhodnutí však považujeme za opodstatněné - právě na učitelích závisí, jak bude komunikace ve třídě nastavena (Mareš, Křivohlavý, 1995; Gavora, 2005), a proto je nutné reflektovat jejich pojetí situace. Učitelé přitom mají jasny záměr, proč komunikaci organizuje určitým způsobem, a cíl, ke kterému daným nastavením směřují - mají vytvořenou představu o ideálním komunikačním schématu, kterému se snaží v reálně hodině přiblížit. $\mathrm{V}$ tomto kontextu můžeme hovořit o subjektivních teoriích učitelů o výukové komunikaci, které jsou součástí jejich pojetí výuky (srov. Mareš et 
al., 1996). Výzkumnou otázku, kterou si klademe, zní takto: Jak učitelé vnímají komunikaci, která v průběhu výuky probíhá mezi nimi a jejich žáky?

\section{Metodologie}

Data, která zde budeme prezentovat, byla pořízena v rámci projektu „Komunikace ve školní tř̌́dě“", který byl řešen na půdě Ústavu pedagogických věd Filozofické fakulty Masarykovy univerzity. Šlo o terénní výzkum etnografického charakteru. Výzkum probíhal v průběhu školního roku 2009/2010, přičemž sběr zahrnoval zúčastněné pozorování ve třídách, videostudie vyučovacích hodin, dotazníky pro žáky a hloubkové rozhovory s učiteli, na jejichž analýzu se především zaměřujeme. Vzorek tvořilo 16 různých trríd druhého stupně základní školy vyučovaných 16 různými učiteli na 4 různých školách. Vyučující, kteří se výzkumu zúčastnili, vyučovali ve sledovaných tř́dách český jazyk, dějepis nebo občanskou výchovu. Zkoumali jsme žáky sedmých až devátých trríd (o metodologii výzkumu více viz Švaříček, 2011).

\section{$3 \mathrm{Z}$ výsledků výzkumného šetření}

Vyučovací hodina stále vyvolává představu učitele, který přednáší svůj monolog, a žáků, kteří spíše jen naslouchají a zapisují si poznámky. Jak však vyplývá z rozhovorů s učiteli, tato představa je dnešní pedagogické realitě vzdálená, což dokládají také data $\mathrm{z}$ našich videostudií - výukový monolog totiž zastává pouze $13 \%$ času vyučovací hodiny, zatímco dialogické formy více než 3,5krát tolik (jedná se o 48 \% času).

Tento stav odpovídá současnému názorovému stanovisku učitelů v našem vzorku, kteří se jednoznačně shodují na tom, že žáci mají v hodinách mluvit. Výuka podle nich zkrátka není předurčena $\mathrm{k}$ tomu, aby byla monologická, ale má mít podobu dialogu: To prostě musí být neustále, neustále odpověd' od těch dětí. (Marie) To, zda žáci s učitelem komunikují (odpovídají, případně sami kladou otázky, což nás opět vrací k stylu vedení výuky, jenž determinuje žákovský komunikační prostor), je totiž chápáno jako distinktivní znak dobré hodiny - hodiny, s níž je učitel spokojený: (Dobrá hodina) to je hodina taková, kdy každý žák řkne svi̊j názor k jakémukoliv tématu, kdy se vyjádř́ a kdy někdo řekne něco zajímavého, nad čím se můžeme pozastavit, a hlavně aby se něco nového dozvěděli. (Veronika).

Vyučovací hodiny, které mají dialogickou podobu, jsou přitom učiteli prezentovány také jako hodiny, které baví samotné žáky, což popisuje např́íklad učitelka Vlasta: Dokonce si do mě rýpnou nebo se zeptají: „, A proč ten? A jak ta půda se v tom, feudum teda je půda, a jak vỉbec se ta půda rozdělovala?" Já kolikrát musím taky ř́ct: „Děcka nevím. “ Já taky veškeré drobnosti a okolnosti nemůžu vědět nebo... takže nad tím spekulujeme spolu, jak asi to mohlo být a jak to asi vyplynulo. To mám pocit, že ta hodina je bavila, když se začnou ptát, a ptaji se, jestli bysme mohli třeba jet na exkurzi zrovna se tam podívat, když mají zájem sami, tak nějak. Tak pak su spokojená a většinou děcka také.

Z rozhovorů s učiteli tak vyplývá, že aby bylo možné vyučovací hodinu považovat za dobrou, musí být založena na střídání interakčních výměn mezi učitelem a žáky. Toho by přitom mělo být možné poměrně snadno dosáhnout, nebot' takto nastavená hodina je na první pohled žádoucí ze strany všech jejích aktérů - vede ke spokojenosti učitelů a baví žáky. $\mathrm{V}$ rozhovorech s učiteli se však opakovaně objevovaly popisy situací, které tomuto ideálnímu modelu v jistém smyslu odporovaly a poukazovaly na to, že jeho nastavení není zcela automatické. Př́ćcinu je přitom podle učitelů nutné hledat na straně žákủ, kteří se do dialogického nastavení výuky nechtějí zapojovat, o čemž vypráví např́íklad učitelka Marie: 
„Hodně, hodně museli mluvit a to se to se prostě dětem, které si potom doma stěžovali rodičům, nelíbilo. Že musí se prezentovat, že musí pořád mluvit.“

Oprávněně tedy vyvstává otázka, co učitele motivuje $\mathrm{k}$ tomu, aby vyučovací hodinu koncipovali jako střídání interakčních výměn, pokud nenacházejí odezvu na straně žáků. Proč je tedy dialogická hodina na rozdíl od hodiny monologické nahlížena jako hodina, která se povedla? Na tuto otázku učitelé nabízejí jasnou odpověd’ „Musí to vyjít od děcek.“ Někteří z učitelů konstatují, že by rádi žákům předávali výukový obsah tradiční transmisivní cestou, ale oni by to od nich „nevzali“. Učitelé v tomto kontextu často hovoří o změně nazírání autority učitele, která dnes již není automaticky přisuzovaná na základě legitimní moci této profese: „Ted'ka si to ten učitel musí mnohem víc jako zasloužit“ (Karel). Jiní učitelé o možnosti vyučování tradičním způsobem nepochybují, nicméně ji neshledávají jako optimální: „Všechno, na co přijdou sami, si zapamatují. Všechno, co musí vydedukovat, nebo $k$ tomu dojdou, to vidíš podle písemek. To, $k$ čemu došli v té hodiné, si pamatují, to, co jim nadiktuješ, vi̊bec" (Alice). Proces učení, který nastává v interakci s učitelem a skrze který k naučenému dojdou žáci sami, je zkrátka vnímán jako jednoznačně efektivní.

Lze tedy říci, že výuková komunikace, tak jak ji učitelé popisují, je vedena tendencí přiblížit se kritériím konstruktivistického vyučování, jež žákům nabízí komunikační prostor, který má být zároveň prostorem pro učení. Učitelé vědí, že takto pojaté vyučování je ve vztahu k vzdělávacím výsledkům účinné a v kontextu aktuálního pedagogického diskurzu žádoucí, a proto se snaží tomuto modelu různými cestami dostát (direktivními kontrolními mechanismy, nebo zezábavňováním, srov. Šed’ová, Švaříček, Šalamounová, 2011), i když ze strany žáků iniciativa a chut' komunikovat v některých chvílích zrovna přímo neprýští. Zde bychom mohli - za využití dat z rozhovorů - učinit závěr. $\mathrm{Na}$ základě triangulace dat však nalézáme příliš mnoho rozporů, které nelze přehlédnout. Nejnápadnějším z nich vyvstane v okamžiku, kdy se optikou našich učitelů zaměříme na problematiku diskuze.

Diskuzi lze chápat jako komunikační formu na míru ušitou prezentovaným požadavkům učitelů. Je založena na dosavadních znalostech a vědomostech jednotlivých žáků, kteří ve vzájemné interakci tyto znalosti sdílejí, a na jejich základě pak dospívají k hlubšímu poznání diskutované reality. Zahrnuje tedy jednak interakci, jednak výstupy ze strany žáků. Diskuze se proto stala také velmi častým (nicméně spontánním) námětem rozhovorů s učiteli, kteří navíc akcentovali její funkci nástroje rozvíjejícího komunikativní kompetence. Přestože tedy diskuze odpovídá tomu, jak učitelé popisují ideální model výukové komunikace, jsou zároveň k možnostem její realizace velmi skeptičtí, a to ze dvou důvodů.

Prvním důvodem, který učitelé opakovaně zdůrazňují jako překážku zapojení diskuze do běžné výuky, jsou dosavadní nedostatečné vědomosti žáků. Učitelé zkrátka poukazují na to, že nelze diskutovat, když nejsou argumenty, což dokládá například učitelka Johana: „Jako pořád je takový ten trend dát jim ten prostor, a aby oni sami, oni sami diskutovali. Já si myslím, že nelze diskutovat, když o tom problému to dítě nic neví. "Diskuze by tedy byla vhodným nástrojem vyučování a učení, nicméně její obsah by byl kvůli míře dosavadních poznatků žáků vyprázdněný.

Druhou, převládající překážkou je nezájem žáků ovládnout pravidla diskuse a pochopit její smysl. Podle učitelů žáci zkrátka nejsou schopni komunikovat: „Oni by asi chtěli mluvit, ale oni to moc neumijou no" (Tereza), což pramenní z toho, že žáci nejsou ochotni si navzájem naslouchat nebo na sebe reagovat: „Ta diskuze je opravdu těžká, že oni málokdy na sebe reaguji, že mně hlavně chtěji prostě ríct to svoje. Mně chtěji říct ten svưj názor" (Veronika).

Je tedy zřejmé, že ačkoli je diskuze formou odpovídající požadavkům, které učitelé kladou na výukovou komunikaci, jsou právě tyto její vlastnosti současně důvodem, proč diskuze podle učitelů nemůže být ve výuce používána. V tomto světle tak lze spatřit onen paradox 
vyplývající z rozhovorů s učiteli: žáci mají ve výukové komunikaci mluvit, a to z toho důvodu, aby rozvíjeli své komunikativní kompetence. Na druhou stranu ale mluvit nemohou, protože komunikativní kompetence doposud rozvinuté nemají. Mají mluvit, protože se touto cestou mohou učit, což ale není možné, protože se potřebné dosud nenaučili. Tento paradox tak může vysvětlovat, proč je zcela převládající dialogickou strukturou vyučovací hodiny již popsaná IRF struktura, komunikační struktura sestávající z otázky učitele, odpovědi žáka a zpětné vazby učitele (srov. Mehan, 1979; Cazden, 1988), která spíše než reálné dialogické formě (srov. Bachtin, 1981, podle Myhill, Jones, \& Hopper, 2007) odpovídá spíše iluzivnímu dialogu (srov. Šed'ová, 2005).

\section{Závěrem}

Můžeme konstatovat, že čeští učitelé hovoří o ideální podobě výukové komunikaci ve shodě s konstruktivistickým diskursem, v závislosti na podrobnější analýze rozhovorů a ostatních zdrojů dat se však ukazuje, že realita výukové komunikace se prozatím pohybuje spíše na půli cesty mezi tradicionalistickým a konstruktivistickým pojetím.

\section{Poděkování}

Autoři děkují všem učitelům a žákům, kteří byli ochotni se výzkumu účastnit, a umožnili tak jeho realizaci. Dále děkujeme za podporu projektům Komunikace ve školní třídě (GA406/09/0752) a Škola: výzkum vnitřních procesů a vnějších podmínek jejího fungování (GA406/09/H040), díky nimž mohl vzniknout tento článek.

\section{Literatura}

Cazden, C. B. (1988). Classroom discourse. Portsmouth: Heinemann Educational Books, Inc.

Gavora, P. (2005). Učitel a žáci v komunikaci. Brno: Paido.

Mareš, J., \& Křivohlavý, J. (1995). Komunikace ve škole. Brno: MU.

Mareš, J., Slavík, J., Svatoš, T., \& Švec, V. (1996). Učitelovo pojetí výuky. Brno: MU.

McCroskey, J. C., Richmond, V. P., \& Richmond, V. (2005). An introduction to communication in the classroom: The role of communication in teaching and training. Allyn \& Bacon, Inc.

McCroskey, J. C., \& Richmond, V. (1983). Power in the classroom I - Teacher and student perceptions. Communication Education, 34, 19-28.

Mehan, H. (1979). Learning lessons. Social organisation in the classroom. Cambridge: Harvard University Press.

Mercer, N. (2010). The analysis of classroom talk: Methods and methologies. British Journal of Educational Psychology, 80(1), 1-14.

Mottet, T. P., \& Beebe, S. A. (2006). Foundations of instructional communication. In T. P. Mottet, V. P. Richmond, \& J. C. McCroskey (Eds.), Handbook of instructional communication (pp. 3-32). Boston: Pearson Education.

Myhill, D., Jones, S., \& Hopper, R. (2007). Talking, listening, learning. London: Open University Press.

Šed’ová, K. (2005). Podoby pedagogické komunikace v české škole: intencionální a iluzivní dialog. Pedagogika, 55(4), 368-381.

Šed’ová, K., Švaříček, R., Makovská, Z., \& Zounek, J. (2011). Dialogické struktury ve výukové komunikaci na druhém stupni základní školy. Pedagogika, 61(1) 13-34.

Šed’ová, K., Švaříček, R., \& Šalamounová, Z. (2011). Komunikace ve školní tř́dě. Praha: Portál. (v tisku)

Švaříček, R. (2011). Funkce učitelských otázek ve výukové komunikaci na druhém stupni základní školy. Studia paedagogica, 16(1), 9-46. 


\section{Kontakt}

Mgr. Zuzana Šalamounová

Mgr. Roman Švaříček, Ph.D.

Masarykova univerzita

Filozofická fakulta, Ústav pedagogických věd

A. Nováka 1, 60200 Brno

e-mail: zmakovska@phil.muni.cz

svaricek@phil.muni.cz

\section{Bibliografické údaje}

Šalamounová, Z., \& Švaříček, R. (2011). Subjektivní teorie učitelů o výukové komunikaci. In T. Janík, P. Knecht, \& S. Šebestová (Eds.), Smišený design v pedagogickém výzkumu: Sborník přispěvkì z 19. výročni konference Čské asociace pedagogického výzkumu (s. 52-56). Brno: Masarykova univerzita.

Dostupné z: http://www.ped.muni.cz/capv2011/sbornikprispevku/salamounovasvaricek.pdf doi: 10.5817/PdF.P210-CAPV-2012-54 